\title{
Балансирование оборонных задач и задач по оказанию помощи гражданскому населению: влияние Covid-19 на роли болгарских Вооруженных сил
}

\section{Tодор Tагарев}

Институт ИКТ, Болгарская академия наук, http://www.iict.bas.bg

Резюме: К военным организациям часто обращаются, чтобы они оказывали содействие в виде конкретных способностей или для усиления гражданского потенциала реагирования в чрезвычайной ситуации внутри страны, в частности, когда необходимы срочные действия в условиях повышенного риска. Чрезвычайная ситуация, связанная с пандемией Covid-19, не стала исключением. Болгарские вооруженные силы уже внесли важный и весьма заметный вклад и готовы выполнять дополнительные задачи, поставленные новым законом о чрезвычайном положении. И общество, и политические элиты ценят это военное участие, и появляются идеи о новых задачах гражданской безопасности, которые можно доверить военным. На основе анализа правовых и доктринальных документов и ответов на интервью, в этой статье представлен обзор внутренних задач болгарских вооруженных сил до пандемии Covid-19, новых задач, поставленных во время пандемии, и возможностей для их решения, и предостережения о дальнейшем расширении спектра внутренних задач армии. Мнения 41 респондента в интервью практически разделились. Незначительное большинство предлагает дальнейшее расширение внутренних задач, выполнение функций резервирования гражданских служб и использование высокотехнологичных возможностей, которыми вооруженные силы уже обладают или планируют развивать. Остальные респонденты рекомендуют проявлять осторожность, обеспечивать эффективность и действенность военного вклада и пересмотреть вновь поставленные форс-мажорные задачи. В статье также представлен контекст принятия решений, сформированный давно откладывающейся 
модернизацией, ограниченным бюджетом и острой нехваткой кадров. Это тот контекст, в котором управляющим органам необходимо найти адекватный баланс между ролями и возможностями в интересах обороны и в интересах оказания поддержки гражданскому населению.

Ключевые слова: менеджмент чрезвычайных ситуаций, кризисный менеджмент, контртерроризм, охрана законности и порядка, оказание поддержки гражданским властям военными, Covid-19.

\section{Введение}

Болгарские вооруженные силы, как и вооруженные силы многих других стран, выполняют три основные функции: защита суверенитета и национальной территории, осуществление вклада в международный мир и безопасность и осуществление вклада в обеспечении внутренней безопасности, особенно во времена кризиса. В мирное время третья из этих ролей наиболее заметна для общества. Вклад вооруженных сил во время пандемии Covid-19 не стал исключением. Неотложность ситуации, неопределенность, связанная с новой вирусной угрозой и ее воздействием, а также ограниченная способность гражданского населения действовать в зараженной среде резко повысили интерес к вкладу вооруженных сил.

В считанные дни новые задачи для вооруженных сил были закреплены в законе. Военный вклад в разрешении чрезвычайной ситуации, связанной с пандемией, пока что в основном рассматривается как положительный, и хотя некоторые из новых задач еще предстоит выполнять, наблюдатели предполагают более широкое участие вооруженных сил. Желание поручать военным новые задачи в их третьей роли может возрасти в предстоящий период выборов без должного учета более широких последствий для обороны.

Исследование, представленное в этой статье, было предпринято с целью прояснить текущую ситуацию, варианты и обоснование вклада вооруженных сил в менеджмент чрезвычайных ситуаций и кризисов на своей территории, а также возможность возложения новых задач на вооруженные силы. Результаты основаны на обзоре соответствующих законов, доктринальных документов и годовых докладов, а также на анализе ответов на анкету. Автор разработал структурированный вопросник ${ }^{1}$ о влиянии Covid-19 на оборонную политику Болгарии в начале мая 2020 года, который был разослан 65 опытным специалистам в области обороны и аналитикам (избегая экспертов из исполнительной власти, которые в настоящее время участвуют в разработке или реализации политики). Сорок один ответ был

1 Steinar Kvale and Svend Brinkmann, InterViews: Learning the Craft of Qualitative Research Interviewing, 2nd ed. (Los Angeles, CA: SAGE, 2009). 
получен вовремя для рассмотрения в этом исследовании. В число респондентов входили действующие члены Комиссии по обороне в Национальном собрании, бывшие министры обороны, бывшие начальники обороны и другие высшие офицеры, научные работники из оборонных академий и исследовательских институтов, а также опытные практики. Респонденты указывали свое имя только тогда, когда они прямо соглашались быть цитированными. В исследование включен контент-анализ ${ }^{2}$ ответов только на первый вопрос, связанный с внутренней ролью и задачами вооруженных сил.

В следующих трех разделах статьи представлены, соответственно, внутренние задачи болгарских вооруженных сил до пандемии Covid-19, новые задачи, поставленные во время пандемии, а также возможности и предостережения в отношении дальнейшего расширения спектра внутренних задач. В последнем разделе очерчены два основных варианта будущего развития и дана связь соответствующего принятия решений и контекста.

\section{Внутренние задачи болгарских вооруженных сил до пандемии Covid-19}

Военная доктрина Республики Болгарии от 1999 г. - первый доктринальный документ, открытый для общественности, - определила в качестве одной из основных целей обороны «защиту населения от стихийных бедствий, промышленных катастроф и опасного заражения в стране и за рубежом ». ${ }^{3}$ Первая Белая книга по обороне и вооруженным силам, опубликованная в 2002 году, четко определила поддержку вооруженными силами гражданских властей и населения как одну из трех основных ролей национальных вооруженных сил, наряду с «Обороной» и «Вкладом в международный мир и безопасность». Согласно Белой книге 2010 г., эта «третья миссия» ${ }^{4}$ включает

... операции по сдерживанию и нейтрализации террористических, экстремистских и преступных группировок; охрана стратегических объектов; защита и поддержка населения при стихийных бедствиях, авариях и экологических катастрофах; обезвреживание боеприпасов; гуманитарная помощь; содействие контролю миграции; поисково-спасательные работы; помощь, при необходимости, другим государственным и местным органам власти для предотвращения и преодоления последствий террористических актов, стихийных бедствий, экологических и промышленных катастроф и опасного распространения инфекционных заболеваний. ${ }^{5}$

2 Alan Brymann, Social Research Methods, 4th ed. (Oxford, UK: Oxford University Press, 2012).

3 Военная доктрина Республики Болгария, одобренная Национальным собранием 8 апреля 1999, Государственная газета, No. 34, 14 апреля 1999.

4 В Белой книге используется термин «миссия», однако, в этой статье в целях соблюдения логики отдается предпочтение термину «роль».

5 Белая книга по обороне и вооруженным силам, одобренная Национальным собранием 28 октября 2010, стр. 21-22, https://www.mod.bg/bg/doc/drugi/201011 30_WP_BG.pdf. Перевод автора. Добавлено подчеркивание. 
В последующих доктринальных документах подробно описаны организационные роли вооруженных сил и процедуры реализации этих ролей вооруженными силами. ${ }^{6}$

До $2015^{7}$ года обезвреживание боеприпасов (ОБ) и участие в борьбе со стихийными бедствиями и защита населения были основными движущими силами для сохранения способностей и готовности для этой роли. Обе задачи требуют регулярного участия вооруженных сил. К 2019 году болгарские вооруженные силы располагали 99 формированиями для предотвращения и восстановления после бедствий и двумя группами для обеспечения эвакуации населения в случае аварии на АЭС «Козлодуй» с общим персоналом 1932 человека и 550 единиц специализированного оборудования, в том числе вертолеты для пожаротушения с воздуха. ${ }^{8}$ В дополнение, десятки мобильных групп ОБ утилизировали 503 взрывных устройства в 2018 году, ${ }^{9}$ и еще 188 устройств в 2019. ${ }^{10}$ Еще одна важная задача - медицинская эвакуация по воздуху, выполняемая ВВС, при этом на дежурстве находятся один военно-транспортный самолет и один вертолет, и команды из Военномедицинской академии. ${ }^{11}$

Тем не менее, детали ожидаемого вклада вооруженных сил в их третью роль оставались в значительной степени неопределенными до миграционного кризиса 2015-2016 годов, который стал еще одним важным фактором для пересмотра и законодательной кодификации внутренних задач вооруженных сил. Две поправки к Закону об обороне и Вооруженных силах уточнили существующие задачи и внесли некоторые новые. ${ }^{12}$ Эти поправки вводят новые законодательные требования для оказания содействия Министерству внутренних дел и другим гражданским организациям, в том числе:

- поддержание готовности и оказание гуманитарной помощи и выполнение спасательных работ на территории и в морской зоне страны и за рубежом;

6 Смотри, к примеру, Доктрина Вооруженных сил Республики Болгария, НП-01 (София: Министерство обороны, ноябрь 2017), https://www.mod.bg/bg/doc/ strategicheski/20171211_Doktrina_VS.pdf.

7 Относительно более ранних анализов, отражающих внутренние контртеррористические роли после 11 сентября, смотри Nikolay Dotzev, "The Soviet Legacy: Transforming Bulgaria's Armed Forces for Homeland Security Missions," Connections: The Quarterly Journal 4, no. 3 (2005): 83-95.

8 Годовой доклад о состоянии обороны и вооруженных сил 2019, проект, внесенный в Народное собрание 16 апреля 2020 (София: Совет министров, 2020), https://www.mod.bg/bg/doc/drugi/20200415_Doklad_otbrana_2019.pdf.

9 Годовой доклад о состоянии обороны и вооруженных сил 2018, одобренный Народным собранием 15 мая 2019 (София: Министерство обороны, 2019), https://www.mod.bg/bg/doc/drugi/20190424_Doklad_2018.pdf.

10 Годовой доклад о состоянии обороны и вооруженных сил 2019, стр. 29.

11 Годовой доклад о состоянии обороны и вооруженных сил 2019, стр. 29.

12 Государственная газета № № 98 и 113 от 2016. 
- содействие органам безопасности в борьбе с распространением оружия массового уничтожения, незаконным оборотом оружия и терроризмом;

- защита стратегических объектов, активов и систем критической инфраструктуры;

- проведение специальных операций по противодействию терроризму и преодолению последствий террористических актов;

- участие в охране государственной границы;

- выполнение полетов специального назначения для нужд других министерств и ведомств. ${ }^{13}$

Все эти задачи требуют дополнительной подготовки и поддержания готовности. Самой сложной из них было военное участие в защите сухопутных границ, в первую очередь границы с Турецкой Республикой. Военные инженеры построили забор на тех участках границы, которые считались более уязвимыми для нелегальной миграции. Сухопутным войскам было поручено содействовать наблюдению и контролю на границе и поддерживать готовность к усилению службы «Пограничной полиции» Министерства внутренних дел составом в размере батальона. В 2017 году среднемесячное участие составляло 240 человек и 70 единиц оборудования. ${ }^{14}$ За первые пять месяцев 2018 года военные предоставили около 700 солдат для выполнения задач по наблюдению и контролю за границей, а также 435 солдат и 234 единицы оборудования для выполнения соответствующих функций материально-технического обеспечения. ${ }^{15}$ Эта операция поддержки была прекращена в мае 2018; тем не менее, вооруженные силы продолжают поддерживать 350 человек в круглосуточной готовности для оказания поддержки «пограничной полиции» в случае, если миграционное давление снова возрастет. ${ }^{16}$

Закон о борьбе с терроризмом, принятый в 2016 году, наделил вооруженные силы типичными правоохранительными функциями при подозрении на террористическую деятельность, включая применение силы. ${ }^{17}$ Для этого от трех служб - военной полиции, бригады специальных операций и Военно-медицинской академии - может потребоваться обеспечить до 1100

13 Закон об обороне и вооруженных силах, статьи 56, 57 и 57а.

14 Годовой доклад о состоянии обороны и вооруженных сил 2017, одобренный Народным собранием 27 сентября 2018 (София: Совет министров, 2018), стр. 35, https://www.mod.bg/bg/doc/cooperation/20181005_Doklad_2017.pdf.

15 Годовой доклад о состоянии обороны и вооруженных сил 2018, стр. 26.

16 Годовой доклад о состоянии обороны и вооруженных сил 2019, стр. 30.

17 Закон о контртерроризме, Государствення газета, №№. 103, 27 декабря 2016, статьи 9-15. 
человек с необходимым вооружением и оборудованием. ${ }^{18}$ Только Сухопутные войска подготовили и поддерживают в постоянной готовности 30 механизированных и альпийских взводов и один модуль ХБРЯ для поддержки контртеррористической деятельности Министерства внутренних дел. ${ }^{19}$

Все эти примеры демонстрируют, что при возникновении необходимости руководство государства готово поручить вооруженным силам вспомогательные задачи и внести соответствующие изменения в правовую базу. У Министерства обороны есть опыт и институциональные механизмы для обеспечения требуемых способностей, поддержания надлежащего уровня готовности и внесения своего вклада, когда это необходимо. Так было и с пандемией Covid-19.

\section{Новые задачи, связанные с пандемией Covid-19}

Неожиданным образом пандемия сделала внутренние роли военных еще более заметными. В стране уже имеется постоянный план действий в случае пандемии гриппа, ${ }^{20}$ в котором, в соответствии с Законом о защите от бедствий, ${ }^{21}$ ведущая роль в управлении отводится Национальному комитету по пандемии с заместителем премьер-министра в качестве председателя и министром здравоохранения в качестве заместителя председателя, а также заместителями министров соответствующих министерств, включая министерство обороны, в качестве членов.

13 марта 2020 года правительство Болгарии объявило чрезвычайную ситуацию и ввело ряд ограничительных мер. Совершенно неожиданно правительство решило создать «Национальный оперативный штаб» (НОШ) и назначило его председателем генерал-майора Венцислава Мутафчийского, профессора, военного хирурга и директора Военно-медицинской академии (ВМА). Руководитель одного из отделений ВМА стал секретарем НОШ. В состав НОШ также входили два других медицинских эксперта - директор Национального центра инфекционных и паразитных заболеваний и государственный санитарный инспектор, а также три старших должностных лица Министерства внутренних дел.

В течение почти двух месяцев НОШ проводил брифинги дважды в день. На брифингах представлялись не только данные, связанные со здравоохранением, такие как количество выполненных тестов, новые случаи инфекции, пациенты в больницах, случаи в отделениях интенсивной терапии, количество смертей и выздоровлений, но и информация о дополнительных

18 Годовой доклад о состоянии обороны и вооруженных сил 2018, стр. 27.

19 Годовой доклад о состоянии обороны и вооруженных сил 2019, стр. 30.

20 Национальный план Республики Болгария на случай грипной пандемии, принятый постановлением \# 5 Совета министров, 13 января 2006. - 109 стр., http://www.strategy.bg/StrategicDocuments/View.aspx?lang=bg-BG\&ld=366.

21 Закон о защите от стихийных бедствий, Государственная газета, №. 102, 19 декабря 2006. 
мерах по сдерживанию пандемии и способах их реализации. Большинство граждан, ограниченных в своих домах, с нетерпением ждали этих брифингов. Генерал Мутафчийский, почти всегда в форме, спокойно и авторитетно говорил как по вопросам здоровья, так и по организационным вопросам. Вскоре он стал нарицательным, получил международное признание ${ }^{22}$ и одобрение более 71 процента болгарских граждан, значительно превзойдя рейтинги любого активного политика. ${ }^{23}$

НОШ оказал такое влияние на менеджмент чрезвычайной ситуации, связанной с Covid-19, что только более внимательные наблюдатели заметили, что он предположительно присутствует только в качестве консультанта. Фактически, закон о чрезвычайной ситуации в связи с Covid-19 возлагал большую часть полномочий по принятию решений на министра здравоохранения, в то время как НОШ упоминается только дважды в его переходных положениях. ${ }^{24}$

Несмотря на юридические полномочия НОШ, Военно-медицинская академия убедительно продемонстрировала свой потенциал в качестве ведущего национального учреждения в сценарии пандемии и свои возможности для:

- тестирования на наличие малоизвестного вируса;

- лечения инфицированных людей (включая большинство заболевших в первые дни пандемии);

- консультирования и обучения других испытательных лабораторий и больниц безопасному использованию защитных масок и защитной одежды в условиях биологической опасности;

- реализации комбинации медико-санитарных и организационных мер по сдерживанию заражения во время пандемии.

Вооруженные силы оказывали и другие виды поддержки. В то время, когда наличная пропускная способность больниц для приема инфицированных вызывала серьезную озабоченность, военные продемонстрировали свою способность развертывать полевые госпитали в столице страны Софии и нескольких других крупных городах страны. Кроме того, в периоды дефицита защитного снаряжения и значительных ограничений для гражданского воздушного движения, Болгария использовала созданную в НАТО многонациональную стратегическую воздушную транспортную способность, и Жасмина Христова, капитан ВВС, приземлила в аэропорту Софии самолет С-17

22 Alexandre Levy, "En Bulgarie, un général deux étoiles héros de la guerre contre le Covid-19," Le Temps, May 1, 2020, https://www.letemps.ch/monde/bulgarie-ungeneral-deux-etoiles-heros-guerre-contre-covid19.

23 «Агентство Сова Харис: Генерал Мутафчийский с самым высоким рейтингом среди болгар», БТВ Новините, 10 апреля 2020, https://btvnovinite.bg/bulgaria/ sova-haris-gen-mutafchijski-s-naj-visok-rejting-sred-balgarite-1.html.

24 Закон о мерах и действиях во время чрезвычайного положения, принятый Народным собранием 13 марта 2020, Государственная газета, № 28, 24 марта 2020. 
«Globemaster», загруженный столь необходимыми медицинскими принадлежностями. В другом примере, еще до объявления чрезвычайной ситуации, Болгарский оборонный институт предоставил результаты испытаний защитных масок и защитной одежды, тем самым подтвердив способность болгарских компаний удовлетворить растущий спрос на высококачественные изделия для защиты медицинского персонала в Болгарии и за границей.

Особенно важным для этого дискурса является разрешение личному составу вооруженных сил выполнять типичные полицейские функции. Закон «О мерах и действиях во время чрезвычайной ситуации» разрешает военнослужащим «совместно и/или в координации с другими органами ... участвовать в реализации контрэпидемических мер и ограничений на территории страны, в определенном районе или на определенном контрольно-пропускном пункте». ${ }^{25}$ Закон оставляет на усмотрение Совета министров определение условий и процедур такого использования вооруженных сил.

Тот же закон разрешает военнослужащим:

1. проверять самоличность человека;

2. ограничивать передвижение лиц, которые отказываются выполнять или не соблюдают карантинные меры, до прибытия представителей Министерства внутренних дел (МВД);

3. останавливать транспортные средства до прибытия представителей МВД;

4. ограничивать передвижение людей и транспортных средств на КПП;

5. использовать физическую силу и соответствующие средства, когда это абсолютно необходимо. ${ }^{26}$

Возложение таких типичных полицейских функций на вооруженные силы вызвало у наблюдателей вопросы. В телеинтервью после принятия закона о чрезвычайном положении министр обороны Красимир Каракачанов заявил, что «участие военных во время чрезвычайного положения начнется сначала с замены Министерства внутренних дел в охране границы, стратегических объектов, посольств и только потом можно думать о патрулирование улиц. ... во-первых, об этом должен запросить министр внутренних дел, а затем Совет министров примет решение [следует ли и как использовать вооруженные силы]». ${ }^{27}$

25 Закон о мерах и действиях во время чрезвычайного положения, статья 9.

26 Закон о мерах и действиях во время чрезвычайного положения, статья 10.

27 «Каракачанов предвидит продление чрезвычайного положения», Сега, 1 марта 2020, https://www.segabg.com/hot/category-bulgaria/armiyata-obyavi-gotovnostda-uchastva-prilaganeto-na-merkite. 
На момент написания этой статьи военные не были привлечены к выполнению таких полицейских функций, и Совет министров не издавал документа, уточняющего положения закона о чрезвычайном положении.

\title{
Будущие задачи болгарских вооруженных сил в рамках их внут- ренней роли
}

Этот раздел статьи основан на ответах экспертов на первый вопрос анкеты:

\begin{abstract}
Что необходимо изменить в задачах, возложенных на болгарские вооруженные силы (отличные от участия в боевых действий), например, пограничный контроль, изоляция территории, создание и функционирование контрольнопропускных пунктов, транспорт, логистика (например, полевые госпитали), обеспечение связи и информационная поддержка, кибербезопасность, противодействие пропаганде и дезинформации и т. д.?
\end{abstract}

Вопрос намеренно включал в примеры три группы задач: (1) некоторые из них, которые уже выполняются военными, например, воздушная транспортировка или участие в пограничном контроле в условиях возросшего миграционного давления; (2) задачи, которые предписаны законом, но еще не выполняются, например, изоляция территории, создание и работа контрольно-пропускных пунктов во время чрезвычайной ситуации и (3) задачи, которые были предметом обсуждения, но, строго говоря, не были возложены на вооруженные силы. К последним относятся кибербезопасность и противодействие гибридному влиянию - области, в которых военные несут ответственность за защиту собственных систем и собственного персонала. ${ }^{28}$ Следовательно, любой ответ типа «военным необходимо выполнить все перечисленные задачи» рассматривается как мнение в сторону расширения внутренней роли вооруженных сил путем возложения новых задач.

Ни один из 41 респондентов не отказался от необходимости или пользы участия военных во время чрезвычайных ситуаций. Далее, на основе контент-анализа, ответы были разделены на три основные группы (см. Фигуру 1):

- 23 респондента - большинство из 56\% - поддерживают выполнение всех перечисленных задач, и некоторые из них предполагают, что военные могут взять на себя еще больше задач по оказанию помощи гражданским властям конкретными способностями или путем добавления потенциала в периоды увеличения спроса, т. е. при чрезвычайной ситуации или во время кризиса;

- Десять респондентов (24,4\%) с осторожностью отнеслись к добавлению новых задач, считая, что они могут иметь неблагоприятное,

28 Согласно Закону о кибербезопасности, «Министр обороны проводит государственную политику защиты и активного противодействия кибератакам и гибридному влиянию на системы командования и управления обороны и вооруженных сил ....». Смотри «Закон о кибербезопасности», Государственная газета, №. 94, 13 ноября 2018, статья 13(1). 
а не положительное влияние на безопасность общества и состояние обороны и вооруженных сил;

- Восемь респондентов, возможно, в соответствии с мнением второй группы, призвали к тщательному и всестороннему анализу всех внутренних задач вооруженных сил, что привело бы к их приоритизации и сбалансированности между тремя военными ролями.

Дальнейшее изложение в этом разделе добавляет детали к экспертным мнениям и разделено на пять тем: возможность увеличения потенциала реагирования на кризис, военное участие конкретными способностями, рекомендуемые организационные изменения, аргументы, обосновывающие проявление осторожности и способы найти надлежащий баланс.

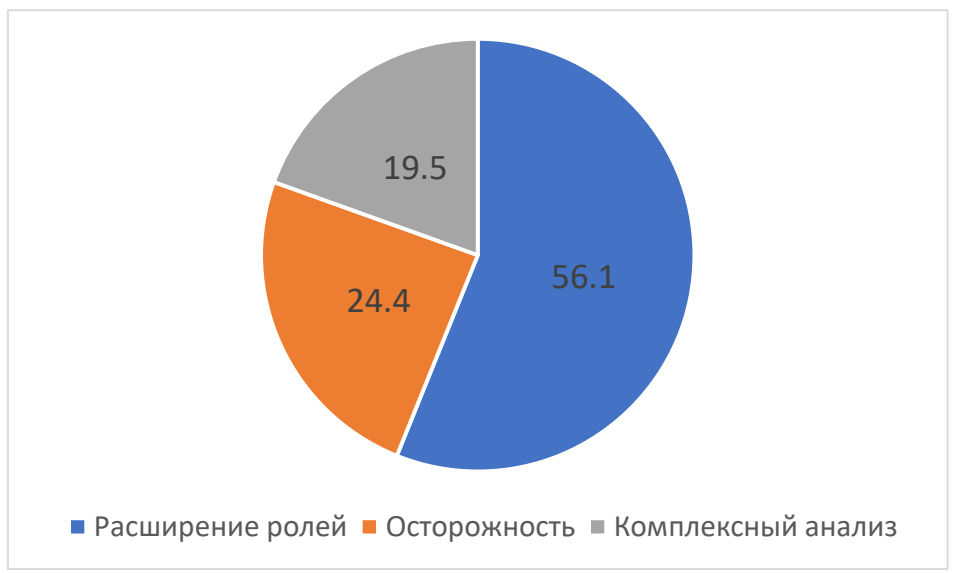

Фигура 1: Распределение реакции в процентах.

\section{Наращивание потенциала}

Большинство опрошенных согласились с тем, что военные должны продолжать играть активную и заметную роль в чрезвычайных ситуациях, предпочтительно в качестве поддержки гражданских властей и вносить свой вклад в достижение решающих результатов.

Как и ожидалось, упор был сделан на использование медицинского потенциала, включая развертывание полевых госпиталей. Один респондент указал, что полевые госпитали могут быть развернуты рядом с международными аэропортами, что позволит прибывающих больных или инфицированных пассажиров эффективно помещать под карантин. Среди связанных с этим задач - ХБРЯ разведка и дезактивация, а также дезинфекция общественных мест и объектов с использованием специальной военной техники.

По мнению полковника Орлина Николова, директора Центра передового опыта НАТО в области кризисного менеджмента и реагирования на 
стихийные бедствия в Софии, в случае масштабного кризиса военные могли бы также помогать гражданским властям и населению:

- $\quad$ развертыванием модулей для полевого проведения тестов (для выявления вирусных или других инфекций);

- созданием мобильных медицинских бригад для обслуживания населения в военных гарнизонах;

- выполнением задач социальной помощи, например, доставкой продуктов питания и медикаментов престарелым и инвалидам, а также лицам, находящимся на карантине (с привлечением курсантов военных академий);

- оказанием психологической помощи населению;

- обеспечением спутникового наблюдения за секторами, представляющими особый интерес.

Несколько экспертов подчеркнули, что вооруженные силы должны опираться на сильные стороны существующего военного потенциала, например, на созданную инфраструктуру командования и управления, на мобильность и способность действовать в зараженной среде. Эти способности могут быть использованы для расширения возможностей Министерства внутренних дел и других гражданских органов по защите критической инфраструктуры и эффективному контролю сухопутных границ. Другие респонденты подчеркнули потенциальные преимущества развертывания групп военной разведки, наблюдения и рекогносцировки (РНP), и беспилотных летательных аппаратов (БПЛА) для усиления наблюдения за границами и за другими представляющими интерес районами.

Несколько респондентов указали на возможности, предоставляемые научно-исследовательским и образовательным сообществом в области обороны при разработке, испытаниях и сертификации новых защитных материалов, организации межведомственного обучения и аналогичных задачах.

Два респондента указали на пока еще не использованный потенциал подразделений и личного состава резерва вооруженных сил.

\section{Добавление способностей}

Эксперты видят преимущества в использовании конкретных военных способностей. Непосредственно с пандемией связаны модули Роль 1 медицинской эвакуации и Роль 2 мобильные передовые медицинские сооружения и хирургические бригады, а также современные способности для биологической защиты. В частности, очевидно, пригодились бы знания и способность бороться с более «экзотическими» инфекционными заболеваниями.

Особый интерес представляют возможности службы «Военная полиция» по созданию и эксплуатации контрольно-пропускных пунктов и выполнению других задач правоохранительных органов. 
Несколько экспертов упомянули возможности вооруженных сил в области связи и киберзащиты. Например, д-р Георги Шарков, координатор по киберзащите, видит возможность для решения задач по обеспечению зашифрованной телекоммуникационной связи, в том числе в мобильной видеоконференцсвязи, и киберзащите критически важных инфраструктур, уделяя особое внимание энергетике, транспорту и здравоохранению.

Один из экспертов указал на потенциальную полезность возможностей для обеспечения координации между гражданскими и военными (CIMIC военно-гражданское сотрудничество), агентурной разведки (HUMINT) и психологических операций. Хотя они разработаны для других целей, они могут способствовать экстренным операциям внутри страны, например, для противодействия распространению фейковых новостей, пропаганды и дезинформации.

Четыре респондента подчеркнули необходимость анализа опыта, накопленного в мероприятиях НАТО и ЕС по реагированию на стихийные бедствия, и поиска наиболее подходящих задач для болгарских вооруженных сил в более широких рамках союзнического и регионального сотрудничества в управлении чрезвычайными ситуациями.

\section{Специальные организационные механизмы}

Несколько респондентов воспользовались возможностью, чтобы предложить организационные изменения, которые, по их мнению, сделают вклад вооруженных сил в обеспечение гражданской безопасности более эффективным.

Контр-адмирал Боян Медникаров, начальник Болгарского военно-морского училища, предложил расширить возможности Военно-медицинской академии и использовать ее в качестве национального медицинского учреждения, специализирующегося на кризисных ситуациях.

Полковник (в отставке) Вилис Цуров, председатель Ассоциации офицеров резерва «Атлантик», призвал к созданию новых видов служб вооруженных сил, включая CIMIC (гражданско-военное сотрудничество) и подразделений для стратегической коммуникации (STRATCOM) для противодействия пропаганде и дезинформации, а также подразделений, которые могут управлять воздушными, надводными и подводными дронами и проводить операции по борьбе с дронами.

Адмирал Медникаров подробно остановился на необходимости создания киберкомандования в вооруженных силах и подразделений для киберопераций на уровне служб, бригад и батальонов. Полковник Орлин Николов поддержал эти идеи, предложив создать подразделения кибербезопасности на уровне бригады и подразделения STRATCOM, которые будут заниматься прежде всего противодействием пропаганде и дезинформации.

Один эксперт ответил, что важность кибернетического и психологического аспекта конфликтов и чрезвычайных ситуаций будет возрастать, и что необходимо будет усилить военно-медицинский и кибер-компоненты. 
Наиболее актуальным организационным решением эксперт считает создание специализированных подразделений батальонного уровня, подчиненных непосредственно министру обороны.

Полковник Цуров считает наиболее подходящим организационным решением создание "Национальной гвардии», которая интегрировалась бы с действующим резервом вооруженных сил и организациями отставных военнослужащих. Национальная гвардия будет специализироваться на функциях поддержки гражданского населения, но при необходимости будет усиливать боевые способности вооруженных сил. ${ }^{29}$

Что касается противодействия пропаганде и дезинформации, адмирал Медникаров предлагает создать организацию национального уровня, которая будет сотрудничать с соответствующими министерствами, включая министерство обороны.

\section{Причины для проявления осторожности}

Четверть респондентов усомнились в необходимости дальнейшего расширения спектра задач, которые ставятся перед военными в их третьей роли. Они считают, что вооруженные силы могут привлекаться для оказания помощи в чрезвычайных или кризисных ситуациях внутри страны, но только в отдельных случаях, когда возможности Министерства внутренних дел превышают требуемые способности. Аргументы в пользу этой точки зрения исходили из двух основных направлений рассуждений: эффективность военного участия и подводные камни, с которыми можно столкнуться. Существует также третья причина - потенциально негативное влияние на боеспособность вооруженных сил, - которая будет рассмотрена в следующем разделе этой статьи.

Даже те респонденты, которые поддерживают расширение роли вооруженных сил, подчеркнули необходимость улучшения интеграции и сотрудничества, проведения регулярных комбинированных тренировок и учений, введения новых учебных программ в военных академиях, которые объединяют военный персонал и представителей гражданских организаций, вносящих свой вклад в антикризисное управление. Один эксперт заявил, что чувствует, что спектр внутренних задач за последние годы слишком быстро расширился. Прежде чем рассматривать новые задачи, необходимо убедиться, что поставленные в настоящее время задачи финансируются в достаточной степени, а соответствующие способности комплексно развиты. Другой эксперт заявил, что добавления новых задач не требуется; вместо этого лучше инвестировать в обучение и повышение устойчивости государственного управления, экономики и общества. Третий респондент подтвер-

29 Относительно более детального обсуждения данной концепции смотри Велизар Шаламанов, Тодор Тагарев и Аню Ангелов, Офицеры резерва: естественный мост между вооруженными силами и гражданским обществом (София: Ентарк, 2006), - на болгарском. 
дил необходимость вкладывать больше средств в комбинированное обучение, а также в обеспечение общей ситуационной осведомленности как гражданских властей, так и военных, участвующих в операциях по урегулированию кризисов, которые могут быть особенно сложными в городских условиях.

Посол Валерий Рачев, полковник в отставке, бывший заместитель начальника военной академии «Г.С. Раковски» и начальник Кабинета Министра обороны, суммировал эти аргументы, заявив, что формальный механизм координации крайне необходим. Этот механизм должен обеспечивать как оперативную координацию, так и сотрудничество на национальном уровне в развитии потенциала для кризисного менеджмента.

Второй тип аргументов лучше всего выразил полковник в отставке Владимир Миленски. По его мнению, действующая правовая база обеспечивает достаточную гибкость, но порой заигрывает с опасными областями:

\begin{abstract}
Дома и в мирное время вооруженные силы могут использоваться исключительно для логистических [в том числе медицинских] задач и, в крайнем случае, для обеспечения связи. Любая задача, потенциально связанная с принуждением собственного населения, такая как «изоляция территории» и создание контрольно-пропускных пунктов, недопустима, независимо от предполагаемой интенсивности использования силы. ... Вооруженные силы - это национальная машина для летального применения оружия, и даже применение «мягкого принуждения» само по себе несет в себе угрозу перехода в более высокую степень жесткости. Где конец этого процесса? Более того, где гарантии недопущения эскалации и прекращения военного вмешательства, когда необходимость в нем отпадает? Каковы будут последствия для имиджа военных и доверия общества к вооруженным силам?
\end{abstract}

В заключение Миленски заявил, что передача таких ролей военным может иметь как непосредственные, так и долгосрочные пагубные последствия для национальной безопасности.

Еще одно предостережение заключается в том, что участие вооруженных сил может привести к усилению зависимости гражданского населения от военного вклада. Это уже происходит в Болгарии, например, при тушении пожаров с воздуха. Еще одна причина для беспокойства заключается в том, что постоянная зависимость от поддержки со стороны военных может помешать развитию более эффективных решений, предоставляемых гражданскими агентствами или коммерческими компаниями. ${ }^{30}$

\title{
В почсках баланса
}

Восемь экспертов, или почти 20 \% респондентов, не ставили прямо под сомнение идею дальнейшего расширения роли вооруженных сил внутри

30 Относительно дальнейшего обсуждения смотри Valeri Ratchev and Todor Tagarev, "Policy and Legal Frameworks of Using Armed Forces for Domestic Disaster Response and Relief," Information \& Security: An International Journal 40, no. 2 (2018): 137-166, https://doi.org/10.11610/isij.4011. 
страны, но заявили, что граница между «традиционными» и новыми военными задачами довольно размыта, и некоторые из дополнительных задачи были добавлены недавно без четкого и объединяющего плана. Они рекомендовали провести всесторонний обзор правовой базы, фактического состояния нынешних способностей, которыми обладают вооруженные силы для выполнения своей третьей роли, а также эффективности и действенности военного вклада на данный момент

Один респондент подчеркнул, что такой обзор должен проводиться в межведомственном формате с использованием набора политически одобренных сценариев планирования. Ожидается, что обзор приведет к составлению списка приоритетных требований и повторному рассмотрению задач, возложенных на вооруженные силы. Несколько респондентов снова подчеркнули необходимость установления четких межведомственных процедур, усиления совместной подготовки гражданских и военных структур и инвестиций в «стратегическую культуру» сотрудничества.

Трое респондентов указали, что такой обзор внутренних задач вооруженных сил должен проводиться в рамках текущего обзора национальной безопасности и Стратегического обзора обороны. Автор разделяет эту точку зрения, поскольку наиболее важной частью обзора обороны будет поиск баланса между боевыми способностями вооруженных сил, их участия в операциях вне страны, направленных на формирование среды безопасности, и вкладом в урегулирование кризисов дома, причем все это будет осуществляться в рамках жестких демографических и финансовых ограничениях.

\section{Варианты для будущего и контекст принятия решений}

На заключительном этапе обзора обороны перед государственным руководством Болгарии стоит выбор: подтвердить существующие задачи, в том числе задачи, поставленные перед вооруженными силами в марте 2020 года, и расширить их, или установить приоритетность этих задач, опираясь на существующие способности для обеспечения эффективной и оперативной поддержки во время кризиса. Вовлечение вооруженных сил в борьбу с пандемией Covid-19 и в менеджмент чрезвычайной ситуации в Болгарии способствовало укреплению общественного доверия и уважения общества к вооруженным силам. В предстоящий период выборов, у некоторых политиков и политических партий может возникнуть соблазн, опираясь на это доверие, призывать к расширению правоохранительной роли военных за пределы чрезвычайной ситуации Covid-19, добавляя новые задачи и/или увеличивая способности и готовность воинских частей оказывать регулярную поддержку гражданским властям и населению.

Как видно из представленного здесь исследования, мнения экспертов разделились почти поровну, с небольшим предпочтением к выполнению широкого спектра задач. Поэтому любое дальнейшее обсуждение в этом отношении необходимо соотносить с надлежащим контекстом. В этом отношении какую-то ясность вносит вывод Ежегодного отчета за 2019 год о 
том, что состояние оборонного потенциала позволяет выполнять конституционно закрепленные роли и задачи, возложенные в рамках коллективной обороны НАТО и Общей внешней политики и политики безопасности Европейского союза, но с учетом «ограничений по времени и охвату». ${ }^{31}$ Для такого вывода есть три основные причины.

Во-первых, болгарские вооруженные силы продолжают рассчитывать исключительно на боевые платформы советских времен. В 2019 году произошел прорыв в виде подписанного (и полностью оплаченного) контракта на приобретение восьми F-16 Block 70. Однако проекты по приобретению бронетехники для трех батальонных боевых групп, двух фрегатов, 3D-радаров и др., подготовка которых велась в течение многих лет, в настоящее время приостановлены. Эти проекты важны для обеспечения оперативной совместимости с союзными силами и соразмерного вклада как в национальную оборону, так и в экспедиционные операции НАТО и экспедиционные коалиционные операции.

Во-вторых, вследствие финансового кризиса 2008 года оборонный бюджет был непропорционально урезан более чем на 37\% (см. фиг. 2). Снижение в реальном выражении продолжалось до 2017 года, когда Совет министров принял «Национальный план по увеличению расходов на оборону до 2 \% ВВП к 2024 году».

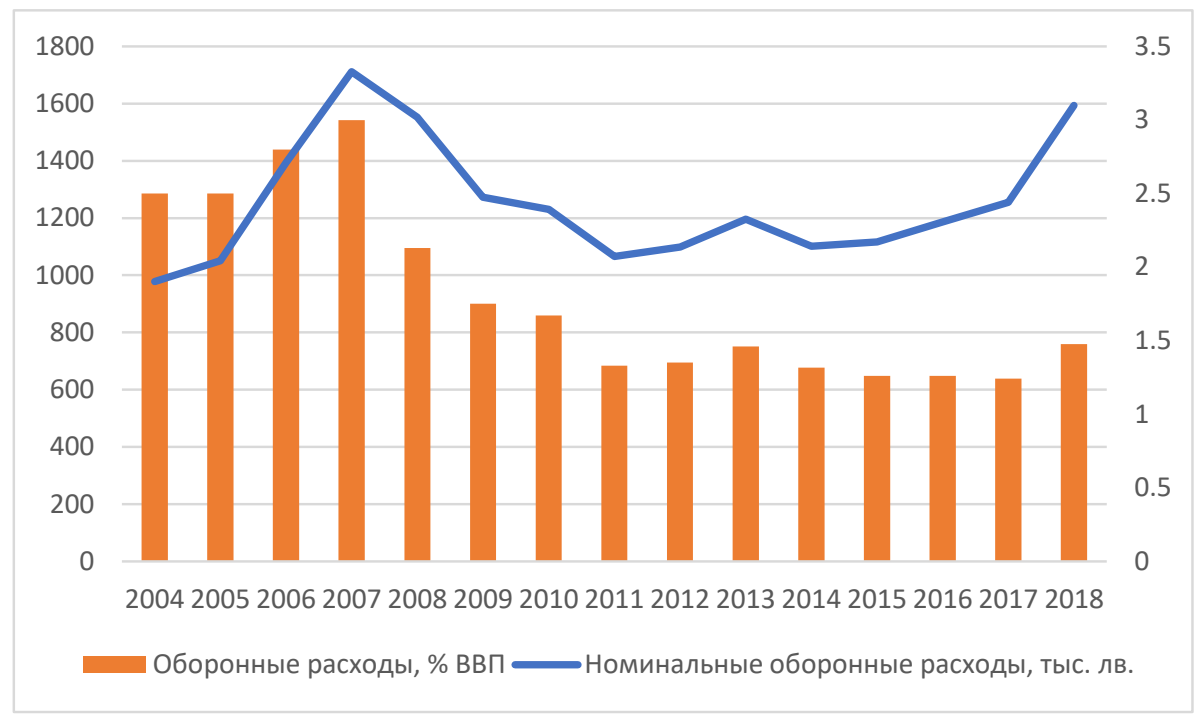

Фигура 2: Оборонные расходы Болгарии, 2004-2018.

Легенда: по вертикали слева в тысячах левах и линия; вертикальная ось справа и колонны в процентах ВВП.

31 Годовой доклад о состоянии обороны и вооруженных сил 2019, стр. 56. 
На практике первое существенное увеличение произошло в 2019 году и касалось закупок F-16. На данный момент неясно, как последствия пандемии Covid-19 повлияют на оборонный бюджет. Однако несколько оппозиционных политиков уже призвали к его сокращению, а одна партия, представленная в парламенте, официально предложила мораторий на все проекты перевооружения и приостановку контракта с F-16. Любое сокращение бюджета или даже задержка в реализации плана его увеличения замедлит перевооружение и отвлечет ценные ресурсы на поддержание старых платформ, которые, кроме того, несовместимы с платформами союзников и препятствуют участию вооруженных сил в операциях и инициативах НАТО и EC.

В-третьих, и это наиболее важно, в течение многих лет министерство обороны не могло обеспечить штатную численность вооруженных сил в 37 тысяч человек. Нынешнее руководство вложило значительный политический капитал в то, чтобы сделать военную службу более привлекательной, например, увеличив вознаграждение и расширив потенциальную базу рекрутов за счет увеличения максимального возраста для прохождения военной службы. К сожалению, переломить негативную тенденцию пока не удается. Согласно годовому отчету за 2019 год, на конец года укомплектованы были менее 80 \% должностей. Эта ситуация особенно тревожна в отношение числа младших солдат и матросов, дефицит которых приближается к 30 \%; Сухопутные войска, которые, как ожидается, обеспечат большую часть резервных способностей во время кризиса, укомплектованы только на 74 \%; и силы специальных операций, которые, как ожидается, внесут ключевой вклад в борьбу с терроризмом, на 27 \% малочисленнее, чем полагается по штатному расписанию. 32

В качестве средства решения проблемы, трое респондентов видят возвращение к сочетанию контрактной и срочной службы. ${ }^{33}$ Другой респондент, возможно, предчувствуя такие предложения, назвал это «забавной идеей, которая поглотит ресурсы, но не принесет результатов». По мнению этого автора, возвращение обязательной службы по призыву может быть полезным, если учесть внутреннюю роль вооруженных сил. Однако его общее влияние будет крайне негативным. Это отвлечет еще больше ресурсов от развития крайне необходимого оборонного потенциала и может оказать пагубное воздействие на национальную безопасность Болгарии.

$$
* * * * *
$$

32 Годовой доклад о состоянии обороны и вооруженных сил 2019, стр. 41.

33 Болгарские Вооруженные силы полностью укомплектовываются контрактниками c 2008. 
Ожидается, что в ближайшие месяцы правительство объявит о своих решениях, основанных на анализе системы национальной безопасности и анализе обороны. Нет сомнений в том, что на обсуждения в последние месяцы анализа сильно повлияет пандемия Covid-19, проблемы, с которыми сталкиваются в процессе менеджмента чрезвычайной ситуацией, и представления о том, что вооруженные силы внесли или могли бы внести в качестве своего вклада. Перед лицами, определяющими политику, стоит задача учесть разнообразные требования и найти сбалансированное решение - в неопределенной экономической и бюджетной обстановке, - которое общество и союзники сочтут приемлемым.

Анализ документов и мнений опытных политиков, практиков и ученых, кратко изложенный в этой статье, поможет в обсуждениях и позволит принять решения, намечающие наиболее адекватный путь вперед. Он также может быть полезным для политиков и аналитиков в других странах, сталкивающихся с аналогичными проблемами.

\section{Отказ от ответственности}

Выраженные здесь взгляды являются исключительно взглядами автора и не отражают точку зрения Консорциума оборонных академий и институтов изучения безопасности ПрМ, участвующих организаций или редакторов Консорциума.

Издание Connections: The Quarterly Journal, том 19, 2020 осуществляется при поддержке правительства Соединенных Штатов.

\section{6 авторе}

Тодор Тагарев - профессор Института информационных и коммуникационных технологий Болгарской академии наук и руководитель его Центра менеджмента безопасности и обороны. Инженер по образованию, профессор Тагарев сочетает в себе опыт работы в правительстве с хорошими теоретическими знаниями и опытом в области кибернетики, комплексных исследований и исследований безопасности - потенциал, эффективно реализованный в многочисленных национальных и международных междисциплинарных исследованиях. https://orcid.org/0000-0003-4424-0201 